\title{
De Copia 1512
}

About Composing in Abundance

\section{Finnegans Wake 1938}

About Cogitation in Helix

\section{The Garden of Forking Paths 1941}

About Forking Time and Being an Abstract Perceiver of the World

\section{Absolute Architecture 1962}

About Materialising the Spiritual

\section{Habitat 1987}

About Being in the Meandering World Unlike Any Other

\section{Blur 2002}

About Making Things Inhabitable out of Nothing

\section{Reincarnation of Norman I 2014}

About Life in Repeated Embodiments 



\section{De Copia}

\section{About Composing in Abundance}

Inside Erasmus of Rotterdam's rhetoric textbook Copia: Foundations of the Abundant Style (1512) (a.k.a. De Copia), we find an exercise in making 150 variations of the sentence "Your letter pleased me greatly." A celebration of abundance (copia) that makes variety possible, and that can "clothe our thought in other colours and other forms." To be precise, it's a twofold abundance of expressions (copia verborum) and matters/ideas (copia rerum).

Your letter mightily pleased me.

To a wonderful degree did your letter please me.

Me exceedingly did your letter please.

By your letter was I mightily pleased.

I was exceeding pleased by your letter.

Your epistle exhilarated me intensely.

I was intensely exhilarated by your epistle.

Your brief note refreshed my spirits in no small measure.

I was in no small measure refreshed in spirit by your grace's hand.

From your affectionate letter I received unbelievable pleasure.

Your affectionate letter brought me unbelievable pleasure.

Your pages engendered in me an unfamiliar delight.

I conceived a wonderful delight from your pages.

Your lines conveyed to me the greatest joy.

The greatest joy was brought to me by your lines.

We derived great delight form your excellency's letter.

From my dear Faustus' letter I derived much delight.

In these Faustine letters I found a wonderful kind of delectation.

At your words a delight of no ordinary kind came over me.

I was singularly delighted by your epistle.

To be sure your letter delighted my spirits!

Your brief missive flooded me with inexpressible Joy.

As a result of your letter, I was suffused by an unfamiliar gladness.

Your communication poured vials of joy on my head.

Your epistle afforded me no small delight.

The perusal of your letter charmed my mind with singular delight.

Your epistle was delightful to a degree. 
Your letter affected me with extraordinary gladness.

As a result of your letter I was affected with singular gladness.

Your epistle was the great joy to me.

Your missive was to me a very great delight.

Your epistle was an incredible joy to me.

How exceedingly agreeable did we find your epistle!

You could scarce credit what relief I find in your missive.

Your epistle was to us one of great delightfulness.

Your letter was very sweet to me.

Your letter was the source of singular gladness.

Your letter made me positively jump for joy.

Your letter having arrived, I was transported with joy.

When your letter was delivered, I was filled with delight.

On receipt of your letter, an incredible delight seized my spirits.

Once I had read your affectionate letter, I was carried away with a strange happiness.

Your epistle poured the balm of happiness over me.

Your writing to me was the most delightful thing possible.

The fact that you had written to me was extremely pleasurable to me.

Your honoring me with a letter was the most agreeable of occurrences.

Your brief note made me burst with joy.

How overjoyed I was by your letter!

I was both pleased and delighted that you communicated with me by letter.

When your letter arrived, you could have seen me jumping on all the joy I felt.

That you paid your respect by letter was assuredly a satisfaction to me.

Nothing more wished for than your letter could have been brought to me.

Your letter has reached us, and eagerly looked for it was.

Nothing more desired than your letter could have been brought us .

Not unpleasing was your epistle tome.

Your by no means displeasing letter has arrived.

Your missive by no means failed of a welcome.

Your epistle was to me the sweetest of the sweet.

I read and reread your letter with great pleasure.

It was not without the greatest pleasure that I received your letter.

The man who delivered your letter conveyed a wealth of joy.

Wonderful to relate how your letter entranced me.

The pages I received from you sent a new light of joy stealing over my heart.

Your letter promptly expelled all sorrow from my mind.

I sensed a wonderful happiness in my spirits when your letter was handed me.

From your letter an unaccustomed happiness swept over my spirits.

Your letter caused me to rejoice to the full.

Because of your letter my whole self exulted with joy.

It is difficult to say how much happiness was occasioned in me by your letter.

I can hardly find words to express the extent of the joy to which your letter gave rise.

It is wonderful to tell what a ray of delight beamed forth from your letter. 
Good God, what a mighty joy proceeded from your epistle!

Heavens, what causes for joy did your letter provide!

Ye gods, what a power of joy did your missive supply!

The happiness occasioned by your communication is greater than I can describe.

Your messenger brought me a deal of pleasure.

You could scarce credit the load of happiness your letter conveyed to my mind.

I cannot find words to tell the joys that your letter loaded on me.

Your letter heaped joy upon me.

I rejoiced greatly at your letter.

I found singular pleasure in your letter.

Your missive showered a wealth of gladness upon me.

At the sight of your letter the frown fled from my mind's brow. 


\section{Finnegans Wake}

\section{About Cogitation in Helix}

What is the best way to read a book written in a delicate mixture of twenty languages centred around English, like a cryptic story, or in a state of text art, still translatable in any language including Chinese? How to read James Joyce's Finnegans Wake...? Joyce spent several months on writing the last 'word' of the book. His final decision was "the", without full stop. A thing that allows the reader to connect back to the beginning of the book: "rivverrun". What happens then? As soon as one begins to reread the whole thing, the same words resonate completely differently. Everything wires anew inside the reader's mind. The first round, the second round, then the third...-One may be able to get a vague feeling of where the spiral is headed, only through (quite a long) time.

riverrun, past Eve and Adam's, from swerve of shore to bend of bay, brings us by a commodius vicus of recirculation back to Howth Castle and Environs. (...)

$$
\text { (...625 pages ...) }
$$

(...) A gull. Gulls. Far calls. Coming, far! End here.

Us then. Finn, again! Take. Bussoftlhee, mememormee! Till thousendsthee. Lps. The Keys to go. Given! A way a lone a last a love a long the 
riverrun, past Eve and Adam's, from swerve of shore to bend of bay, brings us by a commodius vicus of recirculation back to Howth Castle and Environs. (...)

\section{(...)}

(...) Feefee! phopho!! foorchtha!!! aggala!!!! jeeshee!!!! paloola!!!!! ooridiminy!!!!!! Afeared themselves were to wonder at the class of a crossroads puzzler he would likely be, length by breadth nonplussing his thickness, ells upon ells of him, making so many square yards of him, one half of him in Conn's half but the whole of him nevertheless in Owenmore's five quarters. There would he lay till they would him descry, spancelled down upon a blossomy bed, at one foule stretch, amongst the daffydowndillies, the flowers of narcosis fourfettering his footlights, a halohedge of wild spuds hovering over him, epicures waltzing with gardenfillers, puritan shoots advancing to Aran chiefs. Phopho!! (...)

\section{(...)}

(...) A gull. Gulls. Far calls. Coming, far! End here. Us then. Finn, again! Take. Bussoftlhee, mememormee! Till thousendsthee. Lps. The Keys to go. Given! A way a lone a last a love a long the 


\section{Garden of Forking Paths}

\section{About Forking Time and Being an Abstract Perceiver of the World}

In Jorge Luis Borges' 1941 short spy story The Garden of Forking Paths, the narrator Yu Tsun runs away from Captain Richard Madden and arrives at a secluded garden. There, he learns about a novel, in fact, a literary labyrinth, that his ancestor Ts'ui Pên wrote. Professor Steven Albert shows him a letter from Ts'ui Pên, where the following words are written: "I leave to the various futures (not to all) my garden of forking paths." Albert and Tsun discuss why Ts'ui Pên would have sacrificed thirteen years to write the chaotic, nonsensical novel. They solve the riddle and arrive at a conclusion that it is a kind of "rhetorical experiment" on forking time. Shortly after this revelation Madden breaks in; things begin to crystallise in Yu Tsun's forking time.

"Before unearthing this letter, I had questioned myself about the ways in which a book can be infinite. I could think of nothing other than a cyclic volume, a circular one. A book whose last page was identical with the first, a book which had the possibility of continuing indefinitely. I remembered too that night which is at the middle of the Thousand and One Nights when Scheherazade (through a magical oversight of the copyist) begins to relate word for word the story of the Thousand and One Nights, establishing the risk of coming once again to the night when she must repeat it, and thus on to infinity. I imagined as well a Platonic, hereditary work, transmitted from father to son, in which each new individual adds a chapter or corrects with pious care the pages of his elders. These conjectures diverted me; but none seemed to correspond, not even remotely, to the contradictory chapters of Ts'ui Pên. In the midst of this perplexity, I received from Oxford the manuscript you have examined. I lingered, naturally, on the sentence: I leave to the various futures (not to all) my garden of forking paths. Almost instantly, I understood: 'the garden of forking paths' was the chaotic novel; the phrase 'the various futures (not to all)' suggested to me the forking in time, not in space. A broad rereading of the work confirmed the theory. In all fictional works, each time a man is confronted with several alternatives, he chooses one and eliminates the others; in the fiction of Ts'ui Pên, he chooses- 
simultaneously - all of them. He creates, in this way, diverse futures, diverse times which themselves also proliferate and fork. Here, then, is the explanation of the novel's contradictions. Fang, let us say, has a secret; a stranger calls at his door; Fang resolves to kill him. Naturally, there are several possible outcomes: Fang can kill the intruder, the intruder can kill Fang, they both can escape, they both can die, and so forth. In the work of Ts'ui Pên, all possible outcomes occur; each one is the point of departure for other forkings. Sometimes, the paths of this labyrinth converge: for example, you arrive at this house, but in one of the possible pasts you are my enemy, in another, my friend. If you will resign yourself to my incurable pronunciation, we shall read a few pages."

I proposed several solutions - all unsatisfactory. We discussed them. Finally, Stephen Albert said to me:

"In a riddle whose answer is chess, what is the only prohibited word?" I thought a moment and replied, "The word chess."

"Precisely," said Albert. "The Garden of Forking Paths is an enormous riddle, or parable, whose theme is time; this recondite cause prohibits its mention. To omit a word always, to resort to inept metaphors and obvious periphrases, is perhaps the most emphatic way of stressing it. That is the tortuous method preferred, in each of the meanderings of his indefatigable novel, by the oblique Ts'ui Pên. I have compared hundreds of manuscripts, I have corrected the errors that the negligence of the copyists has introduced, I have guessed the plan of this chaos, I have re-established - I believe I have re-established - the primordial organization, I have translated the entire work: it is clear to me that not once does he employ the word 'time'. The explanation is obvious: The Garden of Forking Paths is an incomplete, but not false, image of the universe as Ts'ui Pên conceived it. In contrast to Newton and Schopenhauer, your ancestor did not believe in a uniform, absolute time. He believed in an infinite series of times, in a growing, dizzying net of divergent, convergent and parallel times. This network of times which approached one another, forked, broke off, or were unaware of one another for centuries, embraces all possibilities of time. We do not exist in the majority of these times; in some you exist, and not I; in others I, and not you; in others, both of us. In the present one, which a favourable fate has granted me, you have arrived at my house; in another, while crossing the garden, you found me dead; in still another, I utter these same words, but I am a mistake, a ghost.” 
"In everyone," I pronounced, not without a tremble to my voice, "I am grateful to you and revere you for your re-creation of the garden of Ts'ui Pên."

"Not in all," he murmured with a smile. "Time forks perpetually towards innumerable futures. In one of them I am your enemy."

Once again I felt the swarming sensation of which I have spoken. It seemed to me that the humid garden that surrounded the house was infinitely saturated with invisible persons. Those persons were Albert and I, secret, busy and multiform in other dimensions of time. I raised my eyes and the tenuous nightmare dissolved. In the yellow and black garden there was only one man; but this man was as strong as a statue ... this man was approaching along the path and he was Captain Richard Madden.

"The future already exists," I replied, "but I am your friend. Could I see the letter again?"

Albert rose. Standing tall, he opened the drawer of the tall desk; for the moment his back was to me. I had readied the revolver. I fired with extreme caution. Albert fell uncomplainingly, immediately. I swear his death was instantaneous - a lightning stroke.

The rest is unreal, insignificant. Madden broke in, arrested me. I have been condemned to the gallows. I have won out abominably; I have communicated to Berlin the secret name of the city they must attack. They bombed it yesterday; I read it in the same papers that offered to England the mystery of the learned Sinologist Stephen Albert who was murdered by a stranger, one Yu Tsun. The Chief had deciphered this mystery. He knew my problem was to indicate (through the uproar of the war) the city called Albert, and that I had found no other means to do so than to kill a man of that name. He does not know (no one can know) my innumerable contrition and weariness. 


\section{Absolute Architecture}

\section{About Materialising the Spiritual}

On the opposite side of "form follows function" there are, among others, Hans Hollein and Walter Pichler who wrote the Absolute Architecture manifesto in the 1960s. They wanted to liberate architecture from building. They see architecture as the materialisation of an idea, pure will, powerful thoughts, longings, "most subtle emotions" and "a sensitive record of the most refined sensations." Here, architecture's purpose is not pre-defined, it is absolute, in the sense that it is free from any external functional and contextual limitation of its meaning, therefore, not relative to something else; it is self-reflective. Hollein's part of the manifesto clearly articulates this:

Architecture is a spiritual order, realized through building.

Architecture - an idea built into infinite space, manifesting man's spiritual energy and power, the material form and expression of his destiny, of his life. From its origins until today the essence and meaning of architecture have not changed. To build is a basic human need. It is first manifested not in the putting up of protective roofs, but in the erection of sacred structures, in the indication of focal points of human activity - the beginning of the city.

All building is religious.

Architecture - the expression of man himself-at once flesh and spirit. Architecture is elemental, sensual, primitive, brutal, terrible, mighty, dominating.

But it is also the embodiment of the most subtle emotions, a sensitive record of the most refined sensations, a materialization of the spiritual.

Architecture is not the satisfaction of the needs of the mediocre, is not an environment for the petty happiness of the masses. Architecture is made by those who stand at the highest level of culture and civilization, at the peak of their epoch's development. Architecture is an affair of the elite. Architecture - space-determines with the means of building. Architecture dominates space. Dominates it by shooting up into the heights; it hollows out the earth, projects and soars far above the ground, spreads in all directions. 
Dominates it through mass and through emptiness. Dominates space through space.

This architecture is not a matter of beauty. If we desire beauty at ail, it is not so much beauty of form, of proportion, as a sensual beauty of elemental force.

The shape of a building does not evolve out of the material conditions of a purpose. A building ought not to display its utilitarian function, is not the expression of structure and construction, is not a covering or a refuge. A building is itself.

Architecture is purposeless.

What we build will find its utilization.

Form does not follow function. Form does not arise of its own accord. It is the great decision of man to make a building as a cube, a pyramid or a sphere.

Form in architecture is determined by the individual, is built form.

Today, for the first time in human history, at this point in time when an immensely advanced science and perfected technology offer us all possible means, we build what and how we will, we make an architecture that is not determined by technology but utilizes technology, a pure, absolute architecture.

Today man is master over infinite space.

Hans Hollein 


\section{Habitat}

\section{About Being in the Meandering World Unlike Any Other}

Behind every avatar, a real person. An idea that felt so exciting and seductive in the 1980s. While watching the promotional video of the game Habitat, we are mesmerised by the bright, innocent, utopian vision of being in the "universe unlike any other." In Habitat one can interact with interesting people who are, in principle, anonymous. "Magical events" are the key.

Valentino!? What's goin' on here!? What kind of game you playin' Pops...?!

Pops and his friend Jimmy aren't the first people to get drawn into this strange new world, where names can change as quickly as events, surprises lurk at every turn, and the key modes of existence are fantasy and fun. Here, in a place called Habitat.

Where am I? And who the heck are you??

It is said that boredom once ruled the lifestyles of the avatars and the beings who populate this world. But recently, all that changed, with the birth of an alliance between powerful beings, both here in Habitat and in the human realm...-and with the cooperation of a huge mainframe computer in Virginia. Now, using their modems and Commodore computers, people from Westport to Walla Walla can join Quantum Link and Lucasfilm on an electronic journey, unlike any other. One that leads to Habitat where thousands of avatars, each controlled by a different human, can converge to shape an imaginary society.

Hey, listen. My real name's Henry... they call me Pops... I mean I... No, thickwit... Henry's your human. He's just controlling you. Here you get to be someone else. Well then, I guess I really am Valentino!

Talk about great expectations, Lover Boy. Now lemme be a minute. I've got some digging to do and some treasure to find. 
It is a place full of drama and adventure. A place where a thousand and one things can happen, simultaneously...-making the possibilities here positively unpredictable. So, rest assured, our Mr. Valentino will hardly be alone.

For example, Swelldrella is an avatar controlled by Luann Smith from Beverly Hills. Here, on the quest for a high magic. And high magic is just what she's found, here in a land that lies beyond her wildest dreams.

A Crystal Ball! Oh maybe it will take me away from this dull tropical paradise. What I want is adventure!

Yeah, and what about me?

Ask the oracle. Sooner or later, he'll answer, I promise.

Zipper-de-doo-da, Zipper-de-day!... Mmmmm-mmm-mmmmmmmmm-mmm-mmmm-mmm-mm-mmmm!...

This is one of Habitat's newest recruits, an avatar named Young Turk. He is Conrad Kline, a lawyer with Kline Cates, Kipling and Kline. And right now he is choosing a look that will reflect his real self image, from toe to head. Obviously anxious to show off his true selves. And to get on with his first excursion, Conrad Kline directs his alter-ego avatar, out into the meandering unpredictable world of Habitat, where each and every environment connects to another. With nearly a thousand and one different places to explore, from forests, caves, deserts, and tropical paradise, to Papalopolis, the thriving metropolis.

Hey Bud! Wanna buy this key? Unlocks the secrets of the universe, it does.

Fast action may be the name of the game, for much of the fringe element in Habitat society, but Young Turk is after a different kind of action. His aim is to become one of Habitat's social paraparazzi and to do some plain old-fashioned networking. In fact many an avatar will congregate simply to compare notes about the human realm, to keep up on Habitat's current events, and to socialize. 


\section{Blur}

\section{About Making Things Inhabitable out of Nothing}

Don't forget to wear the Braincoat inside Blur. You might meet "the Hacker, the Provider, the Gene Splicer, the Startup Team, Nutriceutical Pusher, E-tailer, Anarchist, CEO, Pharmacologist, On-line Trader, Executives, Trackers, Researcher, Cyber-Prostitute, Luddite" in the fog. Make sure the fog feels soft and cool to the face. Visit the Water Restaurant and see how polar water tastes.

Location: Expo Headquarters, conference room, Neuchâtel, Switzerland

Attending: Expo officials, Mauro Pedretti, D+S

LIZ DILLER: Water is the dominant material in Blur. Not only does water define the lakeshore site, it is also the main architectural material for the spatial concept and provides the optical effect for the media experience. Water is also a source of culinary pleasure. Depressed one half level below the Angel Deck, large variety of waters from various global sources is available, including a selection of commercially available bottled spring waters, artesian waters, mineral waters, sparkling waters, distilled waters, rainwaters, and municipal tap waters from numerous international cities. An exclusive collection of glacial and polar water is available. Tastings can be arranged for water connoisseurs. 


\section{Reincarnation of Norman I}

\section{About Life in Repeated Embodiments}

Living new lives, in a cycle: whereas Orlando in Virginia Woolf's 1928 novel wakes up as a different gender regularly, effortlessly, and seamlessly, in Matthew Barney's film-opera, River of Fundament (2014) the protagonist Norman is transmogrified through much more ritual-intensive and sculptural transformations. Inspired by Norman Mailer's novel Ancient Evenings (1983), then replacing the protagonist (an ancient Egyptian nobleman Menenhetet I) with the author of the novel himself, Barney's film begins with the ka spirit of Norman ascending from the underworld. Norman is reincarnated as Norman I and Norman II over five hours. Sleek automotive corpses embody them: a 1967 Chrysler Crown Imperial, a 1979 Pontiac Firebird Trans Am, a 2001 Ford Crown Victoria Police Interceptor. Alongside those, primitive materials such as lead and zinc turn into iron and copper, bronze and brass, then toward silver and gold. A glimpse at one of the most powerful scenes of River of Fundament, in which the molten Pontiac Trans Am is cast into a massive iron pillar (DJED), impregnating the spirit of Norman II: 


\section{I B R E T T O}

Casting Pit, Detroit Steel Plant: The Body of Osiris

FULL CAST AND ENSEMBLE

IRON WORKERS

NELPHTHYS (Jennie Knaggs, mezzo-soprano)

BELITA WOODS (Contralto)

5 JAMES LEE BYARS

3 TRASH CONTAINER PERCUSSIONISTS

6 LONG STRING PLAYERS

1 VULTURE

ISIS has been locked in the back of the CROWN VICTORIA, which drives up a long ramp to an embankment wall overlooking a deep excavated pit. Five furnaces stand at the pit's back wall, resembling enormous termite mounds. Smoke billows from the furnaces as IRON WORKERS load them with limestone, coke, and iron. Five 125-foot towers loom over the furnaces. A long figure in the golden costume of JAMES LEE BYARS stands on each tower. As the heat intensifies, the 14 pieces of the IMPERIAL are dumped into the furnaces, where they are reduced to molten iron.

The entire cast and ensemble has made its way into the pit. An accumulation of musical density builds as the furnaces continue to burn. LONG STRING PLAYERS bow and pluck 200 -foot-long amplified cables, which extend from the casting pit up to the top of the towers, while PIT PERCUSSIONISTS pound on three large metal trash containers.

The IRON WORKERS now open the furnaces. Twentyfive tons of glowing orange molten iron flood through small rivers into a reservoir, and overflow into a smaller mold lower in the pit. This is the casting of the DJED. 


\section{NEPHTHYS:}

Khu is a light in the mind of the living, but in death, it must return to heaven

For the Khu is also eternal. Out of the hovering of its wings, there comes a feeling,

Yes, of such tenderness one has never known

For any human, nor received in return-Some sorrowful

understanding

Is in the hovering of the Khu

The DJED and the molten iron remaining in the reservoir slowly fade from orange to gray, as the sky goes dark. A thick metallic gold fluid emerges beneath the figures of JAMES LEE BYARS and slowly flows down the five towers. The voice of BELITA WOODS is now heard as she stands before the CROWN VICTORIA carrying ISIS. A VULTURE is perched on top of the car.

\section{(departure of khu)}

\section{BELITA WOODS:}

Pain took Adobe in the most brilliant light.

He was exposed to burning rock. Demonic,

The heat of the sun, and blood boiling in the veins.

Would it never be blood again?

Cold fires wash behind his sightless eyes as he prepares to leave. ${ }^{2}$ 
